\title{
IMPLEMENTATION OF IMAGINATIVE SUGESTION METHOD BY USING AUDIO VISUAL MEDIA IN LEARNING POETRY WRITING
}

\author{
Andri Firman Budiansah \\ SMP Negeri 3 Cipanas \\ andrie.shadow@gmail.com
}

\begin{abstract}
The research is led by the problems on student's skill in writing poetry in eight grade SMPN 3 Cipanas cianjur. Imaginative suggestion method with audio visual media does not only create comfortable atmosphere but also give suggestion that develop students amaginative skill. The research design used in this study is One Group Pre-test Post-test. The design is aimed to find out the result of the subject and to show how well the final results of each subject. Based on the results, it is shown that there is a significant difference of students' ability of writing poetry before and after using Imaginative Suggestion method With Visual-Audio Media, it is proven by calculation with t-test obtained t arithmetic is 2.68 and t table price t 0,05 ie 2.04. it shows that $t$ count (2.68)> $t$ table (2.04). Then it can be concluded that the results of implementing Imaginative Suggestion method With Visual-Audio Media on Poetry Writing is effective.
\end{abstract}

Keywords: imaginative suggestion method, audio-visual media, poetry writing

\section{PENDAHULUAN}

Keterampilan menulis mengenal jenisjenis menulis, di antaranya menulis puisi, narasi, eksposisi, argumentasi dan persuasi. Dari kelima jenis menulis tersebut yang menarik untuk diteliti adalah keterampilan menulis puisi. Keterampilan menulis puisi memang menjadi satu keterampilan berbahasa yang sulit untuk dikuasai. Hal ini disebabkan adanya unsur yang harus dikuasai oleh penulis, yaitu unsur bahasa, seperti ejaan, struktur kalimat, kohesi, koherensi, serta unsur nonbahasa yang dijadikan ide atau gagasan dalam sebuah tulisan yang meliputi pengetahuan dan pengalaman penulis.

Banyak guru mengalami kesulitan untuk membiasakan anak belajar menulis. Penyebabnya adalah kesalahan dalam hal pengajaran yang terlalu kaku sehingga menimbulkan kesan bahwa menulis itu sulit dan membosankan. Ditambah pula dengan banyaknya guru yang belum memahami pentingnya keterampilan menulis. Belum banyak dari mereka yang bisa menyuguhkan materi pelajaran dengan cara yang tepat dan menarik. Oleh karena itu, wajar jika siswa pun akhirnya tidak mampu dan tidak menyukai pelajaran menulis.

Masalah lain adalah siswa sulit menentukan pilihan kata, menggabungkan kalimat, dan menuangkan ide dalam menulis puisi. Kesulitan ini menyebabkan rendahnya kualitas tulisan siswa baik pada aspek isi maupun kebahasaan. Oleh karena itu, penggunaan metode sangat penting kehadirannya dalam pelajaran.

Untuk menunjang keberhasilan pengajaran bahasa Indonesia terutama menulis dan mencapai hasil optimal, maka perlu diperhatikan faktor intrinsik dan faktor ekstrinsik yang ada pada siswa. Faktor intrinsik di antaranya, motivasi belajar, bakat, persepsi diri dan lain-lain Faktor 
ekstrinsik yakni media pembelajaran dan metode pembelajaran.

Metode pembelajaran mempunyai peranan penting dalam proses belajar mengajar. Salah satunya adalah metode pembelajaran sugesti-imajinatif yang diadaptasi dari metode pembelajaran sugestopedia. Metode sugesti-imajinatif adalah metode yang bertujuan untuk merangsang daya piker siswa dalam pembelajaran terutama dalam pembelajaran menulis puisi.

Di samping metode pembelajaran, media pembelajaran juga dapat digunakan untuk membantu daya pikir siswa dan dapat menciptakan suasana belajar yang menarik perhatian dengan memanfaatkan media pembelajaran yang kreatif, inovatif dan variatif sehingga pembelajaran dapat berlangsung dengan mengoptimalkan proses yang berorientasi pada prestasi belajar.

Salah satu media yang dapat digunakan untuk pembelajaran menulis puisi adalah audio visual.Audio visual adalah media instruksional modern yang sesuai dengan perkembangan zaman (kemajuan ilmu pengetahuan dan tekhnologi), meliputi media yang dapat dilihat dan didengar" (Rohani, 1997: 97-98).

Lebih rinci (Salahudin, 1986:3) menjelaskan bahwa media audio visual adalah merupakan media perantara atau penggunaan materi dan penyerapannya melalui pandangan dan pendengaran sehingga membangun kondisi yang dapat membuat siswa mampu memperoleh pengetahuan, keterampilan, atau sikap. Audio visual pada dasarnya membantu mendorong parasiswadapat mengembangkan minatnya pada pembelajaran, dengan demikian media audio visual dapat digunakan untuk memberikan gambaran tentang sesuatu sehingga penjelasannya lebih konkret daripada yang diuraikan dengan kata-kata.
Menurut Trimantara (2005:3) metode sugesti-imajinasi adalah metode menulis dengan memberikan sugesti melalui lagu untuk merangsang imajinasi siswa. Dalam hal ini, lagu diciptakan sebagai pencipta suasana sugestif, stimulus, sekaligus menjadi jembatan bagi siswa untuk membayangkan atau menciptakan gambaran atau kejadian berdasarkan tema lagu. Melalui khayalan visual, peserta didik dapat menciptakan ideidenya sendiri. Khayalan itu efektif sebagai suplemen kreatif pada belajar kolaboratif. Ia juga berfungsi sebagai batu loncatan menuju penelitian independen yang mungkin pada awalnya Nampak berlebihan bagi peserta didik.

Menurut Mel Silberman (2009:183) prosedur atau langkah-langkah yang akan dilakukan seorang guru menggunakan metode sugesti-imajinasi yaitu sebagai berikut (1) Perkenalkan topik yang akan dicakup. Jelaskan kepada siswa bahwa pelajaran menuntut kreativitas dan penggunaan khayalan visual bisa membantu usaha mereka. (2) Instruksikan pada kelas untuk menutup mata. Dengan menutup mata tanpa menggunakan media lain termasuk tangan, siswa diperkenalkan latihan relaksasi yang memperjelas pikiran-pikiran sekarang dari pikiran para siswa de. Gunakan latar musik, dan pernafasan untuk mencapai hasil maksimal. (3) Lakukan latihan pemanasan untuk membuka mata pikiran. Mintalah para siswa, dengan matanya yang tertutup untuk mencoba memvisualisasikan cahaya dan suara seperti kuntum bunga, kamar tidur mereka, lampu lalu lintas yang berubah, atau rintik hujan. (4) Ketika anggota kelas rileks, siapkan satu khayalan bagi mereka untuk dibangun (5) Ketika anggota kelas rileks, siapkan satu khayalan bagi mereka untuk dibangun. (6) Ketika khayalan dilukiskan, buat suasana kelas tenang dan sunyi sehingga para siswa dapat membangun khayalan visual mereka sendiri. (7) Ketika khayalan dilukiskan, buat suasana kelas tenang dan sunyi sehingga para siswa dapat membangun khayalan visual mereka sendiri. (8) Ketika khayalan dilukiskan, buat suasana kelas 
tenang dan sunyi sehingga para siswa dapat membangun khayalan visual mereka sendiri. (9) Mintalah para siswa untuk membentuk kelompok-kelompok kecil dan saling membagi pengalaman tentang khayalannya dan (10) Setelah berbagi pengalaman mengenai khayalan. Siswa diberi tugas untuk menulis puisi.

Menutut Dale (Arsyad, 2005:4) media Audio Visual adalah media pengajaran dan media pendidikan yang mengaktifkan mata dan telinga siswa dalam waktu proses belajar mengajar berlangsung. Ada tiga jenis media audio visual yaitu jenis media yang selain mengandung unsur suara juga mengandung unsur gambar yang dapat dilihat, seperti rekaman video, berbagai ukuran film, slide suara, dan lain sebagainya. Kemampuan media ini dianggap lebih baik dan lebih menarik, sebab mengandung kedua unsur jenis media yang pertama dan kedua.

Artikel ini dimamsudkan untuk mendeskripsikan kemampuan menulis puisi siswa kelas VIII SMP Negeri 3 Cipanas sebelum diterapkan metode sugesti imajinatif dengan menggunakan media audio visual; untuk mendeskripsikan kemampuan menulis puisi siswa kelas VIII SMP Negeri 3 Cipanas sesudah diterapkan metode sugesti imajinatif dengan menggunakan media audio visual dan; perbedaan kemampuan menulis puisi siswa kelas VIII SMP Negeri 3 Cipanas sebelum dan sesudah diterapkan metode sugesti imajinatif dengan menggunakan media audio visual.

\section{METODE}

Pada penelitian digunakan metode penelitian kuantitatif. Penelitian yang akan dilakukan dalam penelitian mengunakan eksperimen semu (Quasi experiment). Quasi Experimental Design menurut Sugiyono (2016:77):

Bentuk desain eksperimen ini merupakan pengembangan dari true experimental design, yang sulit dilaksanakan. Desain ini mempunyai kelompok kontrol, tetapi tidak dapat berfungsi sepenuhnya untuk mengontrol variabel-variabel luar yang mempengaruhi pelaksanaan eksperimen. Walaupun demikian, desain ini lebih baik dari preexperimental design. Quasi-experimental design, digunakan karena pada kenyataannya sulit medapatkan kelompok kontrol yang digunakan untuk penelitian. Dalam suatu kegiatan administrasi atau manajemen misalnya, sering tidak mungkin menggunakan sebagian para karyawannya untuk eksperimen dan sebagian tidak. Sebagian menggunakan prosedur kerja baru yang lain tidak. Oleh karena itu, untuk mengatasi kesulitan dalam menentukan kelompok kontrol dalam penelitian, maka dikembangkan desain Quasi Experimental. Desain kuasi eksperimen yaitu Time-Series Design dan Nonequivalent Control Group Design.

Desain penelitian merupakan cara yang digunakan untuk mengumpulkan data dalam penelitian, sehingga hasil penelitian dapat diketahui dan dibuktikan dengan jelas.Penulis menggunakan teknik analisis untuk menganalisis data yang diperoleh dari hasil penelitian. Hal ini bertujuan untuk mendapatkan data yang akurat sesuai dengan tujuan penelitian serta mengetahui kesulitan yang dihadapi siswa dalam pembelajaran menulis puisi dengan menerapkan metode sugesti imajinatif dengan menggunakan audio visual.

Dalam penelitian ini penulis
mengguankan jenis one group pretestposttest. Arikunto (2010, hlm. 124), mengatakan one group pretest-postest adalah kegiatan penelitian yang memberikan tes awal (pretest) sebelum diberikan perlakuan, setelah diberikan perlakuan barulah memberikan tes akhir (posttest).

Desain penelitian yang digunakan adalah Nonequivalent Control Group Design, hanya pada desain ini kelompok kontrol tidak dipilih secara random. Nonequivalent Control Group Design yaitu desain yang hampir sama dengan pre test - post test control group design, hanya pada desain ini 
kelompok eksperimen maupun kelompok kontrol tidak dipilih secara random. (Sugiyono, 2016, hlm. 77)

Mekanisme penelitian dari kedua kelas tersebut digambarkan dalam bagan sebagai berikut:

\section{$\mathrm{XO}_{2}$}

Desain Penelitian Tipe The One Group

Pretest Posttest

Keterangan:

$\mathrm{O}_{1}=$ nilai pretes (sebelum diberi perlakuan)

$\mathrm{X}=$ penerapan metode Sugesti Imajinatif dengan Media Audia Visual

$\mathrm{O}_{2}=$ nilai postes (setelah diberi perlakuan)

Pada desain ini, guru melakukan pembelajaran dan memberikan perlakuan dengan menggunakan metode sugesti imajinatif dengan media audio visual pada satu kelas. Sebelum melakukan pembelajaran, penulis memberikan pretest kepada peserta didik. Kemudian, menganalisis isi dan kebahasaan dengan menggunakan metode sugesti imajinatif. Setelah melakukan pembelajaran, memberikan posttest untuk mengukur tingkat keberhasilan pembelajaran yang telah dilakukan.

\section{HASIL DAN PEMBAHASAN}

Bagian ini memaparkan mengenai hasil penerapan metode sugesti imajinatif dengan menggunakan media audio visual dalam pembelajaran menulis puisi pada siswa kelas VIII SMP Negeri 3 Cipanas.

Berikut akan disajikan (a) hasil penelitian pembelajaan menulis puisi sebelum menggunakan metode sugesti imajinatif menggunkan media audio visual (b) hasil penelitian pembelajaan menulis puisi sesudah menggunakan metode sugesti imajinatif menggunakan media audio visual (c) menyajikan perbandingann kemampuan menulis puisi siswa sebelum dan sesudah menggunakan metode sugesti imajinatif menggunkan media audio visual.

\section{Kemampuan Menulis Puisi}

Berdasarkan data hasil perolehan nilai dari kemampuan menulis puisi siswa sebelum menggunakan metode sugesti imajinatif dengan menggunakan audio visual, dapat dilihat bahwa kemampuan siswa dalam menulis puisi masih kurang. Terlihat dari hasil perolehan nilai rata-rata dari kemampuan gaya bahasa menulis puisi dengan nilai 2,43 berarti kemampuan siswa kurang mampu menyampaikan pesan dari gaya bahasa, dilihat dari hasil prolehan nilai rata-rata kekuatan imajinasi adalah 2,3 yang diperoleh berarti kemampuan siswa kurang mampu membangkitkan kekuatanimajinasi bagi pembaca puisi, selanjutnya hasil dari prolehan nilai rata-rata kemampuan ketepatan diksi diperoleh nilai 2,2 yang berarti kemampuan siswa kurang mampu menjalin dan menggunakan kata-kata dalam menulis puisi, dan yang terakhir hasil perolehan nilai rata-rata dari kemampuan menggunakan rima dengan nilai 2,67 yang berarti siswa kurang mampu memvariasi rima akhir yang sesuai dengan pola. Kemampuan mereka juga bisa terlihatdari hasil perolehan nilai rata-rata 48 Nilai rata-rata yang paling dominan pada sebelum menggunakan meode sugesti imajinatif dengan menggunakan media audio visual adalah rima 2,67 (5,56\%) dan nilai rata-rata yang paling rendah adalah pilihan kata (diksi) sebesar 2,2 (4,58\%). Nilai ini akan dibandingkan dengan perolehan nilai sesudah menggunakan metode sugesti imajinatif dengan menggunakan mendia audio visual pada akhir perlakuan. Data hasil akhir perlakuan akan menggambar-kan kemampuan siswa dalam memahami puisi.

Selanjutnya, akan diapaparkan kemampuan menulis puisi siswa sesudah menggunakan metode sugesti imajinatif dengan media audio visual 
Berdasarkan data hasil perolehan nilai dari kemampuan menulis puisi sesudah menggunkan metode sugesti imajinatif dengan menggunakan media audio visual telah mengalami peningkatan. Jika nilai ratarata yang diperoleh sebelum menggunakan metode sugesti imajinatif dengan menggunakan media audio visual hanya 46,3 maka pada akhir perlakuan telah meningkat menjadi 72,16.Terlihat dari hasil perolehan nilai rata-rata dari kemampusan gaya bahasa dengan nilai 4,17 berarti kemampuan iswa mampu menyelaraskangaya bahasa dengan kata konkret, dilihat dari hasil prolehan nilai rata-rata kekuatan imajinasi adalah 3,77 yang diperoleh berarti kemampuan siswa cukup mampu membangkitkan kekuatan imajinasi bagi pembaca puisi, selanjutnya hasil dari prolehan nilai rata-rata kemampuan ketepatan diksi diperoleh nilai 3,2 yang berarti kemampuan Siswa cukup mampu menyesuaikan pilihan kata dengan makna puisi, dan yang terakhir hasil perolehan nilai rata-rata dari kemampuan menggunakan rima dengan nilai 3,3 yang berarti Siswa cukup mampu memvariasi rima akhir yang sesuai dengan pola. berkenaan dengan itu perlu diuji tingkat signifikansinya berdasarkan uji t yang akan penulis kemukakan pada bagian selanjutnya. Berikut adalah tabel distribusi frekuensi yang menyajikan kemampuan menulis puisi siswa sesudah menggunakan metode sugesti imajinatif dengan menggunakan audio visual.

\section{Perbandingan Kemampuan Menulis Puisi Siswa Sebelum dan Sesudah Menggunakan Metode Sugesti Imajinatif}

Berdasarkan dari hasil perbandingan tes awal dan tesakhir bahwa penlitian ini sangat mencolok. Dilihat dari rata-rata nilai mean hasil tes awal hanya mencapai 46,3 (tegolong kurang), sedangkan pada rata-rata nilai mean hasil tes akhir mencapai 72,16 (tegolong cukup baik), ini berarti setelah perlakuan penerapan metode sugesti imajinatif dengan menggunakan audio visual telah terjadi peningkatan yang signifikan.Pada tes awal nilai tertinggi yang dicapai oleh siswa adalah
60. pada tes akhir nilai tertingginya adalah 90. pada tes awal masih terdapat siswa yang mendapatkan nilai di bawah standar ketuntasan belajar minimal (KKM) yaitu 65 . Semua siswa yang mendapatkan nilai di bawah ketuntasan belajar minimal (KKM). Dengan demikian siswa yang memiliki nilai di bawah nilai ketuntasan belajar minimal (KKM) pada awal pembelajaran berjumlah 30 orang atau 100 persen.Pada akhir pembelajaran, siswa yang memiliki nilai di bawah nilai ketuntasan belajar minimal (KKM) hanya 6 orang, siswa yang mendaptakan nilai 60 sebayak 6 orang atau sekitar 20 persen. Jadi siswa yang telah tuntas dalam pembelajaran menulis puisi telah mencapai ketuntasan sebesar 80 persen. Berdasarkan ketentuan Kurikulum Tingkat Satuan Pendidikan (KTSP) 2006 jika guru mengajar dengan ketuntasan belajar pada standar kompetensi tersebut mencapai 80 persen maka telah dapat melanjutkan pada standar kompetensi berikutnya. Tetapi dengan catatan bahwa siswa yang belum mencapai ketuntasan belajar harus diberikan pembelajaran remedial.

1) Menentukan mean dari perbedaan sebelum dan dan sesudah perlakuan

$$
\begin{aligned}
M d & =\frac{\Sigma d}{N} \\
M d & =\frac{725}{30} \\
M d & =24,17
\end{aligned}
$$

2) Menghitung simpangan baku (standar deviasi) nilai pretes dan postes

$$
\begin{aligned}
\text { Sd } & =\frac{\sqrt{\Sigma(y-x)^{2}}}{11-1} \\
\text { Sd } & =\frac{\sqrt{\Sigma(2165-1440)^{2}}}{30-1} \\
\text { Sd } & =\frac{\sqrt{525.625}}{29} \\
\text { Sd } & =18.125
\end{aligned}
$$

3) Menghitung tingkat signifikasi 


$$
\begin{aligned}
& t=\frac{M d}{\frac{\sqrt{\Sigma x^{2} d}}{N(N-1)}} \\
& t=\frac{24,17}{\sqrt{70700}} \\
& t=\frac{24,17}{90(30-1)} \\
& t=2,68
\end{aligned}
$$

Rata-rata nilai yang diraih siswa dalam pembelajaran menulis puisi sebelum mendapat perlakuan berupa metode sugesti imajinatif dengan menggunakan media audio visual adalah 48 (tergolong kurang), dan ratarata nilai yang diraih siswa dalam pembelajaran menulis puisi setelah mendapat perlakuan berupa metode sugesti imajinatif dengan menggunakan media audio visual dalam pembelajaran menulis puisi adalah 72,12 (tergolong baik).

Berdasarkan hasil penelitian yang telah penulis laksanakan, diperoleh hasil bahwa $\mathrm{t}$ tabel dengan jumlah siswa 30 ditribusi t0.975 dan ttabel hargat0.05 yaitu 2,04. Hal tersebut menunjukan bahwa terdapat perbedaan yang signifikan antara hasil pretes dengan hasil postes. Berdasarkan Uji t hitung menunjukan bahwa thitung $>$ ttabel $=2,68>2,04$ artinya $t$ tabel melebihi $\mathrm{t}$ hitung, maka terdapat perbedaan yang signifikan antara kemampuan menulis puisi sebelum dan sesudah menggunakan metode sugesti imajinatif dengan menggunkan media audio visual untuk meningkatkan kemampuan menulis puisi siswa.

Dengan demikian penulis berpendapat bahwa penerapa metode sugesti imajinatif dengan menggunakan media audio visual dalam pembelajaran menulis puisi merupakan pembelajaran yang efektif dan efisien. Karena penggunaan metode sugesti imajinatif dengan media audio visual dalam pembelajaran menulis puisi dapat merangsang daya imajinatif, menumbuhkan minat siswa dan memudahkan siswa dalam menerima materi. Adapun keunggulan dari penerapa metode sugesti imajinatif dengan menggunakan media audio visual dalam pembelajaran menulis puisi in dapat mengatasi keterbatasan pengalaman yang dimiliki oleh siswa, dapat menemukan ide-ide baru, dapat memotivasi belajar siswa, memungkinkan adanya interaksi antara siswa dengan lingkungan sekitarnya dan perhatian siswa khususnya dalam pembelajaran menulis puisi. Pemaparan di atas didukung dari hasil penelitian yang dikemukaan oleh Dida Firmansyah dalam penelitianya bahwa metode sugesti imajinatif melalui media musik merupakan salah satu metode yang efektif untuk digunakan dalam pembelajaran menulis puisi.

\section{SIMPULAN}

Berdasarkan hasil pengolahan data, mulai dari deskripsi data, penerapan dan kemampuan siswa sampai analisis hasil penelitian, dapat dikemukakan beberapa fakta sebagai berikut. (a) Kemampuan menulis puisi siswa SMP Negeri 3 Cipanas Kabupaten Cianjur sebelum mendapat perlakuan berupa metode sugesti imajinatif dengan menggunakan media audio visual masih rendah. Terlihat dari hasil perolehan nilai rata-rata dari kemampuan gaya bahasa menulis puisi dengan nilai 2,43 artinya kemampuan siswa kurang mampu menyampaikan pesan dari gaya bahasa, sedangkan dilihat dari hasil prolehan nilai rata-rata kekuatan imajinasi bernilai 2,3 yang diperoleh berarti kemampuan siswa kurang mampu membangkitkan kekuatan imajinasi bagi pembaca puisi, selanjutnya hasil dari prolehan nilai rata-rata kemampuan ketepatan diksi diperoleh nilai 2,2 yang berarti kemampuan siswa kurang mampu menjalin dan menggunakan kata-kata dalam menulis puisi, dan yang terakhir hasil perolehan nilai rata-rata dari kemampuan menentukan rima dengan nilai 2,67 yang berarti siswa kurang mampu memvariasi rima akhir yang sesuai dengan pola. Kemampuan menulis puisi siswa juga bisa terlihat dari hasil perolehan nilai mean rata-rata dari tes awal pretes sebesar 46,3 (tergolong kurang),dilihat dari nilai rata-rata yang paling dominan sebelum menggunakan meode sugesti imajinatif dengan menggunakan media audio visual 
dalam menentukan rima sebesar 2,67 ( 5,56 $\%$ ) dan dilihat nilai rata-rata yang paling rendah adalah dalam kemampuan pilihan kata (diksi) sebesar 2,2 (4,58\%). Nilai ini akan dibandingkan dengan perolehan nilai sesudah menggunakan metode sugesti imajinatif dengan menggunakan mendia audio visual pada akhir perlakuan. Data hasil akhir perlakuan akan menggambarkan kemampuan siswa dalam memahami puisi.

Dengan demikian hipotesis pertama yang berbunyi "Metode sugesti imajinatif dengan menggunakan media audio visual lebih baik digunakan dalam pembelajaran menulis puisi" dinyatakan diterima. (b) Kemampuan menulis puisi siswa SMP Negeri 3 Cipanas Kab. Cianjur dalam menulis puisi setelah mendapat perlakuan berupa metode sugesti imajinatif dengan menggunakan media audio visual nilai rata-rata mean postes sebesar 72,16(tergolong cukup baik). Terlihat dari hasil perolehan nilai rata-rata dari kemampuan gaya bahasa dengan nilai 4,17 berarti kemampuan siswa mampu menyelaraskangaya bahasa dengan kata konkret, dilihat dari hasil prolehan nilai ratarata kekuatan imajinasi sebesar 3,77 yang diperoleh berarti kemampuan siswa cukup mampu membangkitkan kekuatan imajinasi bagi pembaca puisi, selanjutnya hasil dari prolehan nilai rata-rata kemampuan ketepatan pemilihan kata(diksi) diperoleh nilai sebesar 3,2 yang berarti kemampuansiswa cukup mampu menyesuaikan pilihan kata dengan makna puisi, dan yang terakhir hasil perolehan nilai rata-rata dari kemampuan menggunakan rima dengan nilai 3,3yang berarti siswa cukup mampu memvariasi rima akhir yang sesuai dengan pola.

Dengan demikian hipotesis kedua yang berbunyi "Metode sugesti imajinatif melalui media musik efektif digunakan dalam pembelajaran menulis puisi" dinyatakan diterima. (c) Terdapat perbedaan yang signifikan antara nilai rata-rata mean sebelum perlakuan (pretes) dan nilai rata-ratamean sesudah perlakuan (Postes). Dalam pembelajaran menulis puisi menggunakan metode sugesti imajinatif dengan menggunakan media audio visual dengan thitung $(2,68)$ dan ttabel $(2,04)$ pada taraf kepercayaan $95 \%$.Dengan demikian hipotesis ketiga yang berbunyi 'Metode sugesti imajinatif dengan menggunakan media audio visual dapat meningkatkan kemampuan menulis puisi" dinyatakan diterima. Dengan demikian dapat disimpulkan bahwa metode sugesti imajinatif dengan menggunakan media audio visual merupakan salah satu metode yang efektif untuk digunakan dalam pembelajaran menulis puisi pada siswa SMP Negeri 3 Cipanas Kabupaten Cianjur yang berjumlah 30 orang.

Berdasarkan pengalaman selama proses penelitian berlangsung, dan hasil analisis data, serta kesimpulan yang telah penulis paparkan, berikut ini penulis kemukakan beberapa saran.

Guru harus dapat memilih alternatif pembelajaran yang sesuai dengan karakter bahan pembelajaran, keanekaragaman karakter siswa, serta potensi dan kemampuan pribadi, dengan berwawasan pada lingkungan sekitar sebagai latar nelakang pendidikan.

Metode sugesti imajinatif dengan menggunakan media audio visual merupakan salah satu alternatif metode pembelajaran yang sudah terbukti keefektifannya, terutama dalam pembelajaran menulis puisi pada siswa SMP Negeri 3 Cipanas Kab. Cianjur Bagi Siswa; (1) Siswa harus dapat meningkatkan kesadaran akan pentingnya keterampilan menulis dan dapat lebih meningkatkan efektifitas dan kreatifitas menulisnya tersebut. (2) Metode sugesti imajinatif imajinatif dengan menggunakan media audio visual merupakan salah satu metode yang dapat meningkatkan kemampuan siswa dalam menulis puisi.

Selain ditunjang oleh sarana dan prasarana, serta profesionalisme pengajarnya, keberhasilan proses pembelajaran dipengaruhi oleh keakuratan dalam menentukan suatu alternatif metode pembelajaran yang sesuai. 
(2) Metode pembelajaran yang handal akan .mempermudah proses mengalihkan pengetahuan dari generasi sekarang kepada generasi berikutnya. (3) Metode sugesti imajinatif dengan menggunakan media audio visual merupakan salah satu metode yang terbukti kehandalannya, karena telah melalui suatu proses dan hasil yang teruji dalam suatu penelitian.

\section{DAFTAR PUSTAKA}

Arikunto, S .(2010). Prosedur penelitian suatu pendekatan praktik. Jakarta: Rineka Cipta.

Arsyad, A. (2005). Media pemblajaran. Jakarta: PT Raja Grafindo Persada.

Rohani, A. (1997). Media intruksional edukatif. Jakarta: PT Rineka Cipta.

Salahudin, (1986). Pengertian audio visual dalam pembelajaran, PT. Raja Grafindo. Jakarta

Silberman, M. (2009). Active learning 101 strategi pembelajaran aktif. Yogyakarta: Insan Madani

Sugiyono. (2016).Metodelogi penelitian.Bandung: Alfabeta.

Trimantara, P. (2005). Metode sugesti-imajinasi dalam pembelajaran menulis dengan media lagu. Jurnal Pendidikan Penabur, Vol.5, 1-14. 